\title{
FUTURE TRUSTS FOR A "HUSBAND," "WIFE," OR "WIDOW"
}

\author{
STEWART CHAPLIN
}

The subject to be discussed in this article relates to cases where the owner of real or personal property creates an express trust, after the life of one specified person, to receive and apply the rents, profits and income during the life of that person's surviving "husband," or "wife," or "widow." Trusts thus limited have been held valid under some circumstances because the term was necessarily measured by the life of a "person in being at the creation of the estate," and under other circumstances wholly invalid because the described spouse might prove to be a person who was not thus "in being." The particular question here to be examined is whether, in the class of trusts found to be invalid, it would not be possible by the insertion in the trust instrument of a certain qualifying clause to be suggested presently, to eliminate the fatal defect while still attaining in large degree the result desired by the creator of the trust. 1 Before stating the qualified form of provision referred to, it will be convenient to summarize briefly the legal requirements and the construction which the courts have given in this connection to the terms "husband," "wife" and "widow."

In New York the permissible term of suspension of the absolute power of alienation ${ }^{2}$ and of absolute ownership ${ }^{3}$ is restricted ${ }^{4}$ to "two lives in being." " A similar two-lives restriction with some variations in application is found in the statutes of a fow other states. ${ }^{6}$ In many jurisdictions, in varying and more or less similar connections, the permissible number of lives is not restricted to two. ${ }^{7}$ Under either of these forms of restriction, the question here to be discussed, or questions somewhat resembling it, ${ }^{8}$ may arise. The subject will here be treated with direct

\footnotetext{
1 See also infra note 8.

2 And of postponement of vesting. Matter of Wilcox, 194 N. Y. 288, 298, 300,87 N. E. $497,500,501$ (1909).

3 Ibid. at 306,87 N. E. at 503 .

4 Subject to an exception in the case of real property not here material. See the statutes cited infra note 5 .

$5 \mathrm{~N}$. Y. Cons. Laws (Cahill, 1923) c. 51 , $\S 42,64 ; 1$ N. Y. Rev. Stat. (1829) 723, §§ 14, 15; ibid. 726, § 41; N. Y. Cons. Laws (Cahill, 1923) c. 42 , § 11; 1 N. Y. Rev. Stat. (1829) 773-774, §§ 1-4. See supra noto 4 . 62 Mich. Comp. Laws (1915) §§ 11532-11534; Minn. Gen. Stat. (1023) $\S \S 8044-8046$; Wis. Stat. (1921) §§ 2038-2040.

7 Gray, RULe Against Perpetuities (3d ed. 1915) §§ 214, 216; Marsden, Rule Against Perpetuities (1883) 32.

8 For example, in the "lives-in-being" jurisdictions, the question of the
} 
reference to the restriction to "two lives in being," and in connection with that form of suspension of alienability of real property or of absolute ownership of personal property which is occasioned ${ }^{\circ}$ by express trusts to receive and apply rents, profits and income to the use of individual beneficiaries.

The persons whose lives are thus to furnish the measure of the trust term must be designated in the instrument. For example, it is not sufficient merely to use the words "two lives in being," or the words "during the time prescribed by the statute governing perpetuities." The statute prescribes no time. It requires the creator of the trust to designate two particular persons. It does not expressly speak of "designated" lives, but that requirement is necessarily implied.10.$^{10}$ The purpose of requiring such a designation is to furnish a definite measure of the term. If no particular persons were designated, no one could ever tell when the term had ended. And the persons designated must be "persons in being at the time of the creation of the trust." 11 As applied to our case of a future trust to continue during the life of a person designated in the instrument as the surviving "husband," or "wife," or "widow" of a specified individual, if the descriptive word is such in a given case that one answering to it might possibly prove, at the end of the "first life," to be a person who had not been thus "in being," the designation is fatally defective, even as applied to a surviving spouse who was in fact in being at the creation of the estate." "To render such

validity of a gift limited to vest only upon the death of "the widow" of a specified person. GRAY, op. cit. supra note $7, \$ 214$. In such cases, while it is of no consequence whether the designated lives exceed two in number, the courts are called upon to decide, exactly as in the "two-lives-in-being" jurisdictions, whether the lives that are designated are those of persons "in being," which is the very question presented in given instances by the use of the words "husband," "wife," or "widow." Accordingly, eases from "lives-in-being" jurisdictions are cited infra in many of the footnotes.

9 N. Y. Cons. Laws (Cahill, 1923) c. 51, $\$ 103,105 ; 1$ N. Y. Rev. Stat. (1829) $730, \S \S 63,65$. Stringer v. Young, 191 N. Y. 157, 164, 165, 83 N. E. $690,692,693$ (1908) (personal property).

${ }_{10}$ Woodgate v. Fleet, 64 N. Y. 566, 571 (1876); Matter of Fisher, s. c. sub nom. Matter of Mead, 2 Connelly's Surr. 75, 8 N. Y. Supp. 10 (18s9); Simpson v. Cook, 24 Minn. 180 (1877). As to "lives in being" and remoteness, see GRAY, op. cit. supra note 7 , at $\$ 219 a$; Portman v. Viscount Portman [1922] 2 A. G. 473 ; infra notes $13,20,23,42,47$. As to a designation made by the donee of a power, see the cases cited infra note $\mathbf{8 0}$. As to the scope of the term "designated" see infra notes 32-34.

11 Woodgate v. Fleet, supra note 10, at 571; Mratter of Chitticl, 24: N. Y. 304, 153 N. E. 83 (1926).

12 The case under discussion is to be distinguished from cases where certain provisions may be sustained as valid in spite of the presence of other and separable provisions which are invalid. MIatter of Trevor, 290 N. Y. 6, 17, 145 N. E. 66, 69 (1924) ; Matter of Wilcox, supra note 2, at 201, 87 N. E. at 499 ; Matter of Mount, 185 N. Y. 162, 108, 77 N. E. 999, 1001 
future estates valid, they must be so limited that in every possible contingency they will absolutely terminate," by the end of two designated lives in being. ${ }^{13}$

Thus in Schettler $v$. Smith, ${ }^{14}$ John M. Smith in 1858 made his last will and testament. One share of his estate he devised and bequeathed in trust to receive the rents and income, and pay them to his son John Jacob Smith during life, and then to John Jacob's "wife" during her life. The testator died in January, 1861, and his son John Jacob died in October of the same year having never been married. In an action brought for the construction of the will, the question of the validity of the provision for John Jacob's "wife" was discussed in the opinion of Judge Grover in the results of which a majority of the court concurred. He says: "Now, it is clear, that the son might have married a woman born after the death of the testator, . . . and that such woman might have survived the son; and in the happening of such events, the trust to pay the income to such woman, during her life, would not have terminated upon the death of two persons in being at the death of the testator; consequently the provision . . . might" cause a suspension of alienability for a term not duly measured, and was invalid. ${ }^{15}$ So much for the case of a future trust after one life, the term of which is to be measured by the life of the surviving "wife" of an unmarried man.

By the same will, the testator devised and bequeathed another share of his estate upon similar trusts for the benefit of his son Lawrence S. Smith during life, and then for the benefit of the "wife" of Lawrence during her life. At the date of the will, Lawrence was married, and he and his wife were both living at the death of the testator. The opinion states that if the testator intended to confine his designation to the then living wife of Lawrence, the trust would be valid. The effect would be the same

(1906); Purdy v. Hayt, 92 N. Y. 446, 456 (1883); Schettler v. Smith, 41 N. Y. 328, 336 (1869). As to provisions not thus separable, see Matter of Horner, 237 N. Y. 489, 502, 143 N. E. 655, 659 (1924).

${ }^{13}$ Schettler v. Smith, supra note 12 , at 334, 335; Hawley v. James, 16 Wend. 61 (N. Y. 1836); Amory v. Lord, 9 N. Y. 403, 418, 419 (1853); Matter of Hitchcock, 222 N. Y. 57, 71, 118 N. E. 220, 223 (1917) ; Matter of Mount, supra note 12, at 169, 77 N. E. at 1001. As to "lives in being" and remoteness, see Gray v. Whittemore, 192 Mass. 367,78 N. E. 422 (1906); Ledwith v. Hurst, 284 Pa. 94, 130 Atl. 315 (1925); Ward v. Van der Loeff [1924] A. C. 653, 677-679; LEwIS, PERPETUITY (1843) 170; see supra note 10 and infra notes $20,23,42,47$.

14 Supra note 12.

15 Schettler v. Smith, supra note 12, at 335,336 . See also the opinion of Judge Daniels, ibid. at 343; Tiers v. Tiers, 98 N. Y. 568, 573, 574 (1885); Hayden v. Sugden, 48 Misc. 108, 117, 96 N. Y. Supp. 681, 687 (Sup. Ct. 1905). 
as if he had identified her by name.10 "Ordinarily the use of the word 'wife' in a will means the person who, at the date thereof, is the wife of the man named. An existing fact is referred to." $2 \pi$ Thus we have the rule of construction to be followed in the case of a future trust after one life, the term of which is to be measured by the life of one described merely as the "wife" of a married man.

But in the case of the trust for the "wife" of Lawrence S. Smith, the designation of the second life was not left in that simple form. In other parts of the will the surviving spouse was referred to as Lawrence's "widow," which word standing alone would mean "any surviving wife," and the court found that it was in this sense that the testator had used the word "wife." The trust was therefore invalid." "The use of the word 'widow' . . . involves no fact in existence at the date of the will." 19 "It is difficult to formulate a general rule on the subject, for 'no will has a brother,' and the language of every testator must be studied by itself in order to learn his intention." 20

The use of the words " $a$ " wife, or " $a$ " husband, would also ordinarily mean "any" wife or husband, but this presumption may be controlled by other expressions of the instrument indicating an intent to refer to an existing spouse..21

${ }^{16}$ Schettler v. Smith, supra note 12 , at $348,349$.

17 Meeker v. Draffen, 201 N. Y. 205, 209, 94 N. F. 626, 628 (1911). See also Kiah v. Grenier, 1 T. \& C. $38 s$ (Sup. Ct. 1373), aff'd 56 N. Y. 220 (1874).

is Schettler v. Smith, supra note 12, at 348, 849; Tiers v. Tiers, supra note 15, at 573, 574; Stevens v. MIiller, 2 Dem. 597 (N. Y. Surr. 1881); Lee v. Lee, 2 How. Prac. (N. S.) 76 (N. Y. Sup. Ct. 1885); Wright r. Mercein, 34 Misc. 414, 69 N. Y. Supp. 936 (Sup. Ct. 1901). But in given cases, a reference to both "wife" and "widow" may evidently mean the existing wife. Davis v. Kerr, 3 App. Div. 322, 38 N. Y. Supp. 387 (1806); Allen v. Allen, 149 N. Y. 280,43 N. E. 626 (1896); Beers v. Narramore, 61 Conn. 13, 22 Atl. 1061 (1891); In re Coley [1903] 2 Ch. 102.

19 Meeker v. Draffen, supra note 17, at 209, 9.1 N. E. at 623; Van Brunt v. Van Brunt, 111 N. Y. 178, 19 N. E. 60 (18s8) ; Swallow v. Swallow's Adm'r, 27 N. J. Eq. 278 (1876). As to the effect of divoree, see MIatter of Ensign, 103 N. Y. 284, 8 N. E. 544 (1886) ; Metropolitan Trust Co. v. Bishop, 200 App. Div. 164, 200 N. Y. Supp. 649 (1923), aff d 237 N. Y. 607, 148 N. E. 762 (1924).

20 Meeker v. Draffen, supra note 17, at 209, 94 N. E. at 62S. See also In re Hardyman [1925] Ch. 287; In re Allott [1924] $2 \mathrm{Ch}$. 498; In re Bullock's Will Trusts [1915] $1 \mathrm{Ch}$. 493; In re Garnham [1916] 2 Ch. 418; In re Coley, supra note 18; In re Hancock [1896] $2 \mathrm{Ch}$. 173; In re Drev [1899] 1 Ch. 336; the opinions in which discuss Garratt v. Niblodi, 1 Russ. \& Myl. 629 (Ch. 1830); In re Lyne's Trust, L. R. S Eq. 65 (1869); Boreham v. Bignall, 8 Hare, 131 (Ch. 1850) and other cases cited supra notes 10,

13 and infra notes $23,39,42,47$.

21 Van Brunt v. Van Brunt, supra note 19. 
The adoption as a general guide of the distinction, in the case of a married man, between the terms "his wife" and "his widow," calls attention to one of the difficulties the courts must often encounter, arising out of the eccentricities of language. Such a distinction, if adopted at all, ought naturally to apply equally to the spouse of a married man and the spouse of a married woman. But here enters upon the scene one of the eccentricities mentioned. If the instrument refers merely to the "wife" of a married man, it is reasonable to infer an exclusive reference to the existing wife, and if it refers merely to a man's "widow," it is reasonable to infer a reference to any person who may prove to be his surviving wife. The creator of the trust has a choice of two words which suggest two different intents, and he chooses one or the other, and from the fact of his selection the court may infer his intent. But now suppose that the sexes are, so to speak, shuffled, and that he wishes to refer on the one hand to the existing husband, or on the other hand to "any" husband who may survive a married woman, and sees fit, as often happens, to use only one word for that purpose. The choice which he had before between two words to indicate which was his intent does not now exist. If he uses the word "husband," the courts cannot say with the same force of reason as in the case of the word "wife," that "husband" presumably means the existing husband, for husband is the only word there is to indicate either intent. Even if he intended thus to refer to any surviving husband whatever, he could not be expected to speak, for example, of his then living daughter's "widower." It happens that the word widower is not in as common use in that connection as is the word widow.22 Nevertheless, as a practical matter, it would appear very possible that the courts may apply the same rule of construction to the word "husband" which they have adopted in the case of the word "wife." ${ }^{23}$ However that

22 It is true that if he wished to do something fantastic he might say "my daughter's 'relict." " See Spitler v. Heeter, 42 Ohio St. 100 (1884). But even in the sense of "widow," the word is now only occasionally resurrected for use in obituary notices or on tombstones to describe the widow of a man who was, it seems to suggest, so exalted a personage that his surviving wife should be mentioned by no means as a mere ordinary widow, but as a "relict." It is now "archaic or humorous, except in law." Standard Dictionary.

${ }^{23}$ The presumption would apply only in the absence of controlling indications of a contrary intent. Meeker v. Draffen, supra note 17. A simple rule of construction of that character, based on reasons which would usually be sound, may attain better results than a confused multitude of special rules. Some distinctions, though in a sense "logical," as perhaps this distinction between "husband" and wife," may be so refined that to recognize them would merely be following logic out of the window. "After all, thero is such a thing as common sense." In re Hancock, supra note 20 . The cases, however, which hold that "husband," in given instances, means tho 
may be, we can at least say this: that if there be both married men and married women in question, and the creator of the trust elects in the case of the men to refer merely to "their wives," thus designating their present wives, his use of the term "their husbands" in the case of the women may naturally be construed, as was done in the Van Brunt case, ${ }^{2 *}$ as referring likewise to the existing husbands.

For its bearing on what is to follow, it is now important to recall that in the case of a will it is not the date of execution, but that of the testator's death, that marks "the creation of the estate," and thus the time when the "two lives" must be "in being." ${ }^{25}$ From this it follows that it is not essential to the validity of a testamentary designation of the "second life" that the "husband" or "wife" referred to should be such, or even be living, at the date of execution of the will. It is enough if the designation is confined to "such person as shall, at the testator"s death, be then the husband or wife in question." For example, in the case of the trust for. John Jacob Smith " ${ }^{\circ}$ who was unmarried when the will was made, and where a trust after his death for the life of his "wife" would be invalid, there can be no doubt that if the testator had designated "any woman who shall be his wife at my death, and shall survive him," the trust for the life of such a wife, had she existed, would have been valid. The intent to confine the designation to a person "in being at the creation of the estate" would have been expressly set. forth. ${ }^{27}$

Thus if a testator having three children should provide for one trust to receive and apply rents throughout the lives of "all such children of mine, now living or hereafter born, as shall survive me," and the testator should then die, the term would be measured by three lives, and the trust under the "two lives" rule would be invalid; but if during his life one of his children should die and he left only two surviving, the term would be measured by their two lives, and the trust would be valid. So if, at the execution of that will he had only two children, the trust would be valid if he were then to die; but if during his life a third child were born and the three survived, it would be in-

existing husband, show a tendency to refer for support to special faets and expressions. See Franks v. Brooker, 27 Beav. 635 (Ch. 1860); In Mattcr of Bryan's Trust, 2 Sim. (N. S.) 103 (Ch. 1851); Van Brunt v. Van Brunt, supra note 19, at 186, 19 N. E. at 62 ; cases cited supra note 20.

24 Supra note 19.

25 See the statutes cited supra note 5 .

26 Schettler v. Smith, supra note 12.

${ }^{27}$ Sears v. Russell, 8 Gray, 86, 98 (Mrass. 1857). The intention of the creator of a trust means his intention as indicated in the instrument. But what he thus intends may relate either to facts then existing, or to such as may exist at a later time specified, as for example, in a vill, at the 
valid. ${ }^{28}$ So a testator may designate as a "life" such one of his own children, or of some other person, whether then living or thereafter born, "as may at the time of my death be the youngest of said children"; and the life of such youngest, though born after the execution of the will, constitutes a validly designated life. ${ }^{29}$ It therefore follows that a testator may validly designate as a "second life". "such person as may, at the time of my death, be the husband (or wife) of" a specified individual.

And now, advancing a step further, is there any way in which the creator of a trust may in any case validly designate as a "second life" a husband or wife who may become such after the testator's death, or after the delivery of the trust deed? $\mathrm{He}$ evidently could do so, for example, by naming a then living woman, and providing that in case she should at any time thereafter become the wife of an individual specified, the trust should continue after the first life for her benefit during her life. But the present question is whether the creator of the trust could in any way validly designate as the second life "such person [not personally identified by name] as may hereaftex at any time during said 'first life' become the spouse" of a specified person. John M. Smith, for example, ${ }^{30}$ desired and attempted to desig-

death of the testator. Meeker v. Draffen, supra note 17, 208, 209, 04 N. E. at 628; McLean v. Freeman, 70 N. Y. 81, 87 (1877); Matter of Thompson, 217 N. Y. 111, 115, 111 N. E. 762, 763 (1916); Matter of Gaffken, 197 App. Div. 257, 188 N. Y. Supp. 852 (1921), aff'd 233 N. Y. 688, 135 N. E. 971 (1922). As to a deed signed on one date with a view to delivery later, and dealing with facts as they may exist with reference to the date of delivery, see the New York statutes cited supra note 5; Van Cott v. Prentice, 104 N. Y. 45, 10 N. E. 257 (1887) ; Portman v. Viscount Portman, supra note 10; of. FARWELL, PowERS (1874) 226.

28 Griffin v. Ford, 1 Bosw. 123, 137 (N. Y. Super. Ct. 1857); Lang v. Ropke, 5 Sandf. 363 (N. Y. Super. Ct. 1852); Lang v. Wilbraham, 2 Duer, 171 (N. Y. Super. Ct. 1853); DuBois v. Ray, 7 Bosw. 244, 300 (N. Y. Super. Ct. 1860) ; Butler v. Butler, 3 Barb. Ch. 304, 311 (N. Y. Ch. 1848) ; Galway v. Brice, 10 Misc. 255, 257, 30 N. Y. Supp. 985 (Sup. Ct. 1894); McArthur v. Scott, 113 U. S. 340, 382, 5 Sup. Ct. 652 (1885); Dungannon v. Smith, 12 Cl. \& F. 546 (H. L. 1845); Southern v. Wollaston, 16 Beav. 276 (Ch. 1852) ; FARWELL, op. cit. supra note 27, at 226; Lewis, op. cit. supra note 13, at 27, and its supplement (1849) 53,57; MARSDEN, op. cit. supra note 7, at 67 ; GRAY, op. cit. supra note 7, \$ 231 . In Odell v. Youngs, 64 How. Prac. 56 (N. Y. Com. Pl. 1882) the judge before whom the caso was tried held that Griffen v. Ford, supra, and Lang v. Ropke, supra, had been overruled on this point. In this he was mistaken, and his statement of the law is not correct. See Judge McAdam's review of the subject in Tallman v. Tallman, 3 Misc. 465, 23 N. Y. Supp. 734 (Sup. Ct. 1893) and the cases cited infra note 29.

29 Jacoby v. Jacoby, 188 N. Y. 124, 131, 80 N. E. 676, 678 (1907); Cogan v. McCabe, 23 Misc. 739, 52 N. Y. Supp. 48 (Sup. Ct. 1898) and cases there cited; Simpson v. Cook, supra note 10; Sears v. Russell, supra note 27 ("any husband of my daughter, living at my death"); infra note 47 .

so Schettler v. Smith, supra note 12. 
nate "any such wife" as his son John Jacob, then unmarried, might thereafter marry and leave surviving. That provision was invalid. But it is believed that there is a form of description which the testator could have employed which, in case John Jacob had married, even after his father's death, and had left a wife surviving, would have rendered the trust valid under some (and those the most probable) circumstances. For now suppose that John M. Smith, while retaining the provision for John Jacob's "wife," had eliminated the "possibility" that caused the invalidity. This he could have done by defining the term "wife" so as expressly to exclude any person not living at the testator's death, and to include any wife whatsoever whom John Jacob might at any time marry, if in fact she should be a person who was living when the will took effect. ${ }^{31}$ This form of description represents the suggested clause heretofore referred to. It might, for example, read thus: "And from the death of my son John Jacob, to receive and apply the rents and income to the use and during the life of any wife whom he may at any time maxy and leave surviving, and who shall be a person who was in existence at the time of my death." Against such a designation the sole objection already mentioned would find no ground for its support.

If, then, John Jacob had later married a women born after the testator's death, she would simply not answer to the description in the will. No trust for her would have been attempted. But if under the proposed provision John Jacob had later married, and left surviving a per'son who was living at the testator's death, the trust for her would then have been saved by virtue of that provision. Without this form of description the law would be compelled to assume that John Jacob might possibly, after biding his time for a couple of decades or so, marry a woman born subsequent to the death of the testator. In fact he died nine months after the testator. If in the interval he had married, his wife would necessarily have been a person in being at the creation of the estate. He could not have married a person nine months old. But the courts would still, in that event, have been obliged to test the validity of the term, not by what had happened, but by what might possibly have happened. The trust for the wife, though in fact a person eligible for designation as the "second life," would have been invalid. Yet if, in the event of such a marriage during the nine months, the suggested clause had been in the will, it would, by spilking the unlawful "possibility," have saved the trust for the wife.

So in the case of the trust after the death of Lawrence S.

31 See the statutes cited supra note 5 for the definition of the term "creation of the estate"; and see supra note 27. 
Smith, the testator's married son, ${ }^{32}$ for any wife he might leave surviving. His wife, Ann Eliza, who was his wife at the date of the will in 1858 and at the testator's death in 1861, was still living when the construction of the will was before the court in 1869. But the trust was held invalid because as viewed from the time when the will took effect (1) she might die before Lawrence and (2) he might marry again and (3) his substituted bride might have been born after January, 1861, and (4) she or some other and equally disqualified woman might be his wife at the time of his death. And yet, if the suggested clause had been in the will, and if his wife Ann Eliza or any later wife born before the testator's death should survive him, the trust for the "second life" would have been saved. Or such, at least, would be the result unless that clause is subject to some legal objection or qualification not yet considered.

Does the description given in the proposed clause constitute what is meant by the requirement that the second life must be "designated"? The proposed form, it might first be objected, does not designate the person by name. But such an identification is not required. Thus the designation of the "wife" of a married man is just as definite as though her name had been inserted. ${ }^{33}$ So the designation of "such child of mine as shall, at the time of my death, be the youngest of my children," is adequate. ${ }^{34}$

Another objection might be that under the suggested form, and until the termination of the "first life," the personal identity of the person designated to represent the "second life" would continue unknown. But it is not necessary that the identity of that person should be known during the pendency of the first life, either to the trustee or to the beneficiary or to the creator of the trust if, as in the case of a trust created by deed, he is still living or should even be capable of discovery until the first life ends. Thus a grantor created a trust to pay the income of property to Mrs. Howland and her three daughters, who were living at the creation of the trust, during the life of the grantor (which thus constituted the "first life"). He further provided that at his death the principal should be disposed of in accordance with sealed instructions delivered with the deed but not to be opened until the grantor's death. During the life of the grantor, he was the only one who knew what the instructions contained. When, at his death, the sealed paper was opened, it was found to continue the trust for the same beneficiaries until the majority of such one of the three daughters (persons in

32 Schettler v. Smith, supra note 12.

33 Ibid. at 338; Fitchie v. Brown, 211 U. S. 321, 329, 29 Sup. Ct. 106, 108 (1908).

34 Supra note 29. 
being at the delivery of the deed) as should, at the death of the grantor, be the youngest of them then living. The life of such youngest survivor constituted the "second life." During the grantor's life, even he did not know which of the three daughters might prove to be the particular one by whose minority the second portion of the trust term would be measured. The designation was sustained as valid..$^{35}$

And in Schermerhorn v. Cotting, ${ }^{36}$ Amos Cotting created testamentary trusts for the benefit of his wife, his son and his daughter. During the lifetime of the wife, the income was to be divided into three parts, and one part was to be paid to each of the three beneficiaries. Thus the life of the wife constituted the first life. At the termination of this first life, the whole estate was to be divided into two equal and independent trusts, one in favor of the son and the other in favor of the daughter. As to each of these shares, the life of the respective child constituted the second life. But it occurred to the testator that he should make special provision for the event that one of the children might die during the first life. He accordingly provided that in that case, and upon the death of his wife, the entire income should then be paid to the son (if he was the sole survivor) during his life, and if the daughter was the sole survivor, then the entire income was to be paid to her during her life. The court said:

"It has appeared that in the contingency of the death of the son before the wife, the trust term was limited by the lives of the wife and daughter, while upon the other contingency, viz., the death of the wife before the son, the trust in the one-half of the estate was limited by the lives of the wife and son, . . . The two lives which govern the duration of the trust in one contingency are not the same two lives which govern its duration in the other. Does this circumstance render the trust void? I do not see why it should. . . . The wife is the one person whose life is counted in both contingencies, and in the one the daughter is added and in the other the son; but one or the other of the two contingencies must happen, and in no event is the trust to endure longer than two selected lives in being at its creation. Such a provision does not run counter to the views upon which our statute against perpetuities is based.

Where a trust is created which by no possibility and in no contingency can endure longer than during the existence of two lives in being, of what consequence can it be that if one contingency happen, the estate is to be measured by two named lives, and that if the other contingency happen, the estate is still to be measured by two named lives, but one of them is different from the one named in the other contingency? So long as both contingencies cannot happen, the number of lives upon whose duration the trust term is to be limited cannot be more than two actually named and in existence when the trust was

35 Van Cott v. Prentice, supra note 27, at 57.

36131 N. Y. 48, 29 N. E. 980 (1892). 
created. - . . So long as the trust can last but two lives, which two shall be the selected ones may be left to the happening of a contingency such as exists in this case." ${ }^{37}$

In such a case there is at no time during the entire term any uncertainty about the identity of the particular life "in being" on which its continuance is then depending. ${ }^{38}$

The doctrine of these cases thus appears to be decisive in favor of such a form of designation as has here been suggested, unless one distinction now to be mentioned interferes with that result. For in the cases just examined, the "second life," though not itself specifically identifiable at the creation of the estate, was at any rate described as being that of one or another, as the facts might turn out by the end of the "first life," of certain individuals each one of whom was personally identified in the instrument. And in the foregoing quotation from the Schermerhorn case, the court, in speaking of the will before it, says that "the number of lives upon whose duration the trust term is to be limited cannot [under that will] be more than two actually named and in existence when the trust was created." But in our suggested clause on the contrary, there is no such limited group of identified persons, some one of whom, by the end of the "first life," must, if the trust is then to continue, become known as the particular "second life." If any "group" is to be found in it, it consists, in effect, of all the men or women in existence at the creation of the estate. For, as a matter of legal theory, any woman in all the world might be, or become, eligible to marry the specified man and might be persuaded by him to do so; or any man in all the world might prove to be the surviving husband of the specified woman. Accordingly, the question arises whether the presence of a group of specifically identified eligibles constituted a controlling reason for the decisions rendered, or was merely an accidental and unessential circumstance which happened to exist in those cases. Now the statutes say nothing about any group of eligibles. Nor is there any "general policy" of the law from which any such requirement could be derived. ${ }^{39}$ Furthermore, there is a practical difficulty which stands in the way of acceding to the necessity of naming such a group.

${ }^{37}$ Ibid. at $62,63,29$ N. E. at $982,983$.

38 For illustrations of invalidity due to uncertainty, see Brown v. Evans, 34 Barb. 594 (N. Y. Sup. Ct. 1861) ; Bean v. Hockman, 31 Barb. 78 (N. Y. Sup. Ct. 1859).

39 Thus under the New York law of powers, the beneficiary of a trust for his life may be empowered to designate by his will a further life during which the suspension shall continue. He may thus, for example, designate his wife if she is a person in being at the creation of the power. It is not necessary to provide him with a list of eligibles. Hillen v. Iselin, 144 
For what, in that connection, would be the meaning of the word "group"? Just how many people might validly be included in it? In naming a group of eligibles from whom the "wife" must be selected, would it do to name ten women, or a hundred, or a thousand, or all female descendants of any person who came over in the Mayflower, or of any person who had been listed in Who's Who in America? Where could the line be drawn? And if it were said that the test must be found in the ease and certainty with which membership in the group might be ascertained, that difficulty would at once disappear by enlarging the group still further to consist of all existing descendants of Adam and Eve, or, in other words, as in our proposed clause, "any surviving wife or husband who shall have been in being at the creation of the estate." In short, any limitedgroup theory would be hopelessly vague and impractical. Under the proposed clause, when the time comes to identify the person, that person, if there is ever to be one answering to the description given, will at once be known. At the death of the specified man, for example, the terms "any surviving wife," or "the widow," could not refer to more than one person, as in the case of a certain Ann Eliza, or Frances, or Nellie, or Florence, or Jennie. ${ }^{11}$ No matter how industrious and efficient the man

N. Y. 365, 378, 39 N. E. 368, 372 (1895); Crooke v. County of Kings, 97 N. Y. 421 (1884); Maitland v. Baldwin, 70 Hun, 267, 270, 21 N. Y. Supp. 29, 31 (Sup. Ct. 1893).

The same holds true in limiting a remainder after an estate for one life or two lives to such person as shall, when the time for vesting arrives, answer to a given description. Meeker v. Draffen, supra note 17, at 209, 94 N. E. at 628 ; Course v. Chapman, 158 N. Y. 466,47 N. E. 812 (1897); Kelso v. Lorillard, 85 N. Y. 177 (1881); Mead v. MTitchell, 17 N. Y. 210 (1858); see also In re Bullock's Will Trusts, supica note 20, and In re Garnham, supra note 20.

The cases in this note, which obviously differ in many respects from the case under consideration, are here cited merely on the question of the existence of any "general policy" requiring the designation of a group of eligibles. Those relating to powers, however, would appear to lend direct support to the form here suggested. See GraY, op. cit. supio note 7, $\$ 517$, et seq.

40 Any requirement, in jurisdictions where a term is measured by "lives," instead of "two lives" that the number must be so limited that the espiration of the term may be definitely ascertained (GRIr, op. cit. simio note 7, § 217; IIARSDEN, op. cit. supra note 7, at 32; Fitchie v. Brown, supre note 33 ) has no bearing where a second life is to be ascertained at the expiration of one life specified.

${ }^{41}$ See Schettler v. Smith, supra note 12; Mieeker v. Draffen, supre note 17; Durfee v. Pomeroy, 154 N. Y. 583, 49 N. E. 132 (1898); Matter of Harris, 152 App. Div. 52, 136 N. Y. Supp. 711 (1912), aff'd 206 N. Y. 600, 99 N. E. 1108 (1912); Williams v. Alt, 226 N. Y. 2S3, 123 N. E. 499 (1010).

In addition to future trusts for a surviving spouse, we have those where there is a gift to the spouse, or to others upon the death of that spouse. Sears v. Russell, supra note 27; Swallow v. Swallow's Adm'r, supra note 19; 
might be in negotiating successive matrimonial alliances, and even though at his death there should appear a galaxy of competing alleged widows, their claims could not affect the validity of the trust instrument, and there would be no legally insoluble problem in identifying the one, if any, who answered to the description given. And to determine whether the surviving spouse so identified is, as specified in the instrument, a person who was "in being" at the creation of the estate, would present no more difficulty than in any case where, after the lapse of years, a date of birth must be ascertained.

Many other methods of qualifying and thus rendering valid what would otherwise have constituted illegal measures of the term are found in the reports, and lend full support, in reason, to the form under discussion. Thus, as illustrations, we have the following: A trust after A's life for the life of a person described merely as his "widow" is invalid. But if the designation were confined to his existing wife it would be valid.42 So a trust after A's life for the life of a specified daughter, in being at the creation of the estate, is valid.43 So if a testator leaves three or more children surviving him, a trust in his will to continue until the youngest of them to reach majority shall do so, is, under the "two lives" rule, not duly measured; but if the designation is confined to the one who is the youngest at the testator's death, it is duly measured.44 So if a testator creates after one life, a separate trust for the life of each of several persons living at his death, and for the life of each of several persons who might thereafter be born, the former might be sus-

cases cited above in this note. Such cases may or may not involve suspension of alienability or remoteness, but they all present the same question arising in the trust cases of determining who was meant by the designations "husband," or "wife," or "widow." See infra notes 42, 47.

42 Supra notes 16-19. So with the necessity that remainders, to be valid, must be so limited that they will certainly vest, if ever, by the end of the prescribed period. A gift to vest only upon the death of the "widow" of the testator's son is invalid; but if the will adds: "or at the death of my son, if he leaves no widow," the latter gift is valid. Schettler v. Smith, supra note 12, at 336-339; see also Kiah v. Grenier, supra note 17, 56 N. Y. at 225; Matter of Wilcox, supra note 2; In re Bullock's Will Trusts, supra note 20; GRAY, op. cit. supra note 7, $\S \S 247,332$; MARSDEN, op. cit. supro note 7, at 103; In re Harvey, L. R. 39 Ch. D. 289 (1888) ("any husband"); Tiers v. Tiers, supra note 15 ("any widow"); Matter of Horner, supra noto 12, at 496; Tichenor v. Mechanics' Nat'l Bank, 96 N. J. Eq. 560, 125 Atl. 323 (1924) ;' Overby v. Scarborough, 145 Ga. 875,90 S. E. 67 (1916); Shewmake v. Robinson, 148 Ga. 287,96 S. E. 564 (1918); Sears v. Russell, supra note 27 ("any surviving husband," "any present or future husband"); Gray v. Whittemore, supra note 13; In re Allott, supra note 20 ("the surviving husband, if any").

43 Manice v. Manice, 43 N. Y. 303, 385 (1871).

44 Jacoby v. Jacoby, supra note 29 , at $130,131,80$ N. E. 677,678 ;

Van Cott v. Prentice, supra note 27, at 57, 10 N. E. at 262. 
tained, while the latter are invalid.4 MIany other illustrations might be added. The proposed clause follows the same lines by merely eliminating the possibility of illegality. If in its case the same conclusion of validity were not to follow, the result would constitute nothing less than a legalistic nightmare. ${ }^{\text {s }}$

Indeed, the proposed method of saving trusts which would by themselves be valid from contamination by others that are invalid is so simple, and its validity and efficiency are so clear, that this detailed discussion might call for an apology, were it not for the fact, so far as concerns the trust instruments dealt with in the reports, that such an antiseptic provision appears almost never to have been resorted to, ${ }^{47}$ and that attempted trusts, for the lack of it, have actually gone down in the general ruin. As applied to future trusts of the class here in question, the results of the discussion may now be briefly summarized.

Subject to variation by special indications of intent, these results are as follows:

(1) Invalid designations of the "second life" are, for example, those found in the mere term "the wife" of a man then unmarried;" or "the widow," "or "any" husband, or wife,, "s of a person then either married or unmarxied. The reason for the invalidity is that a surviving spouse thus described might pos-

45 Matter of Mount, supra note 12, at 16S-170, 77 N. E. at 1001, 1002. See MIatter of Horner, supra note 12, at 503,143 N. E. at 660; Matter of Trevor, supra note 12.

46 For an instance of the actual use in a will of the form here under discussion, see infra note 47 .

${ }_{47}$ One instance of a testator's use, in substance, of this form has been found in the reports. In IIetropolitan Trust Co. v. Bishop, supra note 19, at $165,200 \mathrm{~N}$. Y. Supp. at 650 , the will, after creating a trust for each of the testator's children, used these vords: "In case of the death of any one of my sons leaving him surviving a wife born before my death, to pay one-third of the income of the said share to said wife quarterly as long as she shall live, . . ." See also Portman v. Viscount Portman, supra note 10 , at 491 .

In Sears v. Russell, supra note 27, there vas a devise to vest only upon the death of "any present or future husband" of the testator"s daughter. This was held void for remoteness, but the court said that it would have been valid if it had been limited upon the death of "any husband of my daughter, living at my death." These words may, however, mean nothing more than "any husband who shall have been such at my death."

To the effect that a devise in terms similar to those in the will last referred to would have been valid if limited to vest absolutely at the death of one specified person in being, with a mere postponement of pozzession during the life of "any widow" of the specified person, see Klingmon :. Gilbert, 90 Kan. 545, 135 Pac. 682 (1913). Cf. In re Bullock's Will Trusts, supra note 20; In re Garnham, supra note 20.

48 Supra notes $14,15$.

49 Supra notes $18,19$.

so Supra notes 15, 18. 
sibly prove to be a person who was not in being at the creation of the estate.

(2) Valid designations of the "second life" are, for example, those found in the mere term "the wife" of a man then married "t (and also, very possibly, by analogy, "the husband" of a woman "then married) ${ }^{52}$ and, in a will, "any person who" at the testator's death, shall then be the husband, or wife, of one either married or unmarried at the date of the will..53 The reason for the validity is that a surviving spouse thus described will certainly be a person who was in being at the creation of the estate.

(3) Where a designation of the "second life" would otherwise be broad enough to include "any" spouse who might become such after the creation of the estate, and would thus fall into the invalid class, yet if the instrument ${ }^{54}$ should restrict the designation to "any such" surviving husband, or wife, or widow, as should in fact prove to be a person who was in being at the creation of the estate, the case would thereby be withdrawn from the invalid class because the reason for inclusion therein would be absent, and would pass over into the valid class because the reason for inclusion therein would be present. While that restrictive form cannot and does not seek to protect (because the law forbids) a trust after one life for the further life of a spouse who proves to have been not thus "in being," it would be effective (as the other forms of expression dealt with in the reports were not) to scotch the "mere possibility" doctrine, and thus to save the trust for any surviving spouse who does in fact prove to have been thus "in being." ${ }^{55}$

\footnotetext{
51 Supra notes $16,17$.

- 52 Supra notes 22-24.

${ }^{53}$ Supra notes 25-29. As to a deed, see supra note 27.

54 Whether will or deed, see supra note 31 .

55 And also to save a remainder limited to vest upon the expiration of the second life thus designated. See Sears v. Russell, supra note 27; and supra notes $41,42,47$.
} 